\section{Analysis of anti-Müllerian hormone $(A M H)$ and its receptor (AMHR2) genes in patients with persistent Müllerian duct syndrome}

\author{
Pesquisa de mutações nos genes do hormônio antiMülleriano \\ (AMH) e do seu receptor (AMHR2) em pacientes com \\ síndrome de persistência dos ductos Müllerianos
}

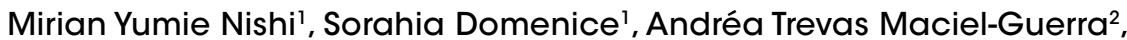
Alberto Zaba Neto', Marcia Alessandra Cavalaro Pereira da Silva², Elaine Maria Frade Costa', Gil Guerra-Junior², Berenice Bilharinho de Mendonca'

\begin{abstract}
Objective: To screen for mutations in $A M H$ and $A M H R 2$ genes in patients with persistent Müllerian duct syndrome (PMDS). Patients and method: Genomic DNA of eight patients with PMDS was obtained from peripheral blood leukocytes. Directed sequencing of the coding regions and the exon-intron boundaries of $A M H$ and $A M H R 2$ were performed. Results: The $A M H$ mutations p.Arg95*, p.Arg123Trp, c.556-2A>G, and p.Arg502Leu were identified in five patients; and p.Gly323Ser and p.Arg407* in AMHR2 of two individuals. In silico analyses of the novel c.556-2A $>$ G, p.Arg502Leu and p.Arg407* mutations predicted that they were harmful and were possible causes of the disease. Conclusion: A likely molecular etiology was found in the eight evaluated patients with PMDS. Four mutations in $A M H$ and two in $A M H R 2$ were identified. Three of them are novel mutations, c.556-2A>G, and p.Arg502Leu in $A M H$; and p.Gly323Ser in AMHR2. Arq Bras Endocrinol Metab. 2012;56(8):473-8
\end{abstract}

\section{Keywords}

AMH; AMHR2; anti-Müllerian hormone; hernia inguinalis; persistent Müllerian duct syndrome

\section{RESUMO}

Objetivo: Analisar os genes $A M H$ e $A M H R 2$ em indivíduos com síndrome de persistência dos ductos de Müller (SPDM). Pacientes e método: Amostras de DNA genômico de oito pacientes com SPDM foram obtidas de leucócitos de sangue periférico. Sequenciamento direto da região codificadora e das áreas intrônicas próximas aos éxons dos genes $A M H$ e $A M H R$ foi realizado. Resultados: As mutações p.Arg95*, p.Arg123Trp, c.556-2A>G e p.Arg502Leu no gene $A M H$ foram identificadas em cinco pacientes e as mutações p.Gly323Ser e p.Arg407* no gene AMHR2, em dois indivíduos. As análises in silico das mutações c.556-2A>G, p.Arg502Leu e p.Arg $407^{*}$, não descritas anteriormente na literatura, previram que elas são deletérias e possivelmente a causa da doença. Conclusão: Uma provável etiologia molecular foi encontrada nos oito pacientes portadores de SPDM avaliados. No gene do $A M H$ foram identificadas quatro mutações e no AMHR2, duas mutações. Três das seis mutações encontradas são mutações novas, c.556-2A>G e p.Arg502Leu no gene $A M H$; e p.Gly323Ser no AMHR2. Arq Bras Endocrinol Metab. 2012;56(8):473-8

\section{Descritores}

AMH; AMHR2; hormônio anti-Mülleriano; hérnia inguinal; síndrome da persistência dos ductos Müllerianos
1 Unidade de Endocrinologia do Desenvolvimento, Laboratório de Hormônios e Genética Molecular LIM42, Disciplina de Endocrinologia, Hospital das Clínicas, Faculdade de Medicina da Universidade de São Paulo (HC-FMUSP), São Paulo, SP, Brazil ${ }^{2}$ Grupo Interdisciplinar de Estudos da Determinação e Diferenciação do Sexo, Faculdade de Ciências Médicas, Universidade Estadual de Campinas (FCMUnicamp), Campinas, SP, Brazil
Correspondence to: Mirian Yumie Nishi

Unidade de Endocrinologia do Desenvolvimento, Laboratório de Hormônios e Genética Molecular LIM42, Disciplina de Endocrinologia e Metabologia, Hospital das

Clínicas, Faculdade de Medicina da Universidade de São Paulo Av. Dr. Enéas de Carvalho Aguiar, 155, PAMB, 2andar, Bloco 6 05403-900 - São Paulo, SP, Brazil minishi@usp.br

Received on July/31/2012 Accepted on Sept/10/2012 


\section{INTRODUCTION}

Tormal development of male internal and external - genitalia during embryogenesis depends on the action of testicular hormones: anti-Müllerian hormone $(\mathrm{AMH})$ and testosterone. AMH is secreted by Sertoli cells and acts on its receptor in the Müllerian ducts, determining their regression. Testosterone, secreted by testicular Leydig cells, acts on the androgen receptor in the Wolffian ducts inducing the formation of epidydimis, deferent ducts, and seminal vesicles. Testosterone is further reduced to dihydrotestosterone (DHT) by the enzyme $5 \alpha$-reductase 2 , which acts on the androgen receptor of the prostate and external genitalia, determining their masculinization (1). The development of female internal genitalia in a male individuals may occur due to the incapacity of Sertoli cells to synthesize or secrete $\mathrm{AMH}$, or due to alterations in type II AMH receptor.

Patients with persistent Müllerian duct syndrome (PMDS) have normal male phenotype, and the presence of an uterus and Fallopian tubes is usually discovered during corrective surgery for inguinal hernia or cryptorchid testis (2). Leydig cell function is preserved, but azoospermia is common, due to the malformation of the ductus deferens or agenesis of the epididymis (3). The testes are usually adhered to the uterine tubes, and may be located in the abdominal or inguinal region. Hernia uteri inguinalis is a condition where the testes and Müllerian derivatives are found within a hernia inguinalis, and when the testes descend through a single inguinal canal, this is known as a transverse testicular ectopia.

The anatomical abnormalities common to all patients with PMDS lie in the failure of the gubernaculum to anchor the testes in the base of the scrotum. Migration of the gubernaculum to the scrotum creates a processus vaginalis in which one or both testes, accompanied by Müllerian derivatives, may cause hernias (4). Abnormal mobility of the testes facilitates their torsion and may lead to uni- or bilateral testicular degeneration (3).

The testes are not often connected to the ejaculatory ducts due to aplasia of the epididymis and the upper portion of the deferent duct or, secondarily, to the disassociation between the epididymis and testis caused by the presence of the Müllerian derivatives. The vas deferens is generally short and strongly associated with the uterine wall. Testicular histology is often normal, with the presence of spermatogonia, except in cases of long duration cryptorchidism. The presence of testicular germ cell tumors in adults patients, sometimes, may lead to an unexpected discovery of Müllerian derivatives (5).
PMDS is a heterogeneous disorder that is inherited in a sex-limited autosomal recessive manner. Occurrences in several members of some families have already been described (6). The phenotype can be produced by a mutation in the gene that encodes anti-Müllerian hormone, or by a mutation in type II AMH receptor gene. These two forms result in the same phenotype and are referred to as PMDS type I and type II, respectively.

The $A M H$ gene was cloned in 1986 by Cate and cols. (7). $A M H$ is a small gene containing five exons located in chromosome 19pl3.3 (8), and its protein product acts by means of its specific type II receptor $(A M H R 2)$, a serine/threonine kinase, member of the family of type II receptors for TGF- $\beta$-related proteins (8). Several mutations in $A M H$ have already been described (Figure 1) (9-11).

The AMHR2 gene, located in 12q13, was cloned in 1994 by two different groups $(12,13)$. AMHR2 contains 11 exons and more than 27 mutations have already been described in this gene (Figure 1) $(5,9,14)$.

The aim of this study is to screen for mutations in $A M H$ and $A M H R 2$ genes in patients with PMDS.
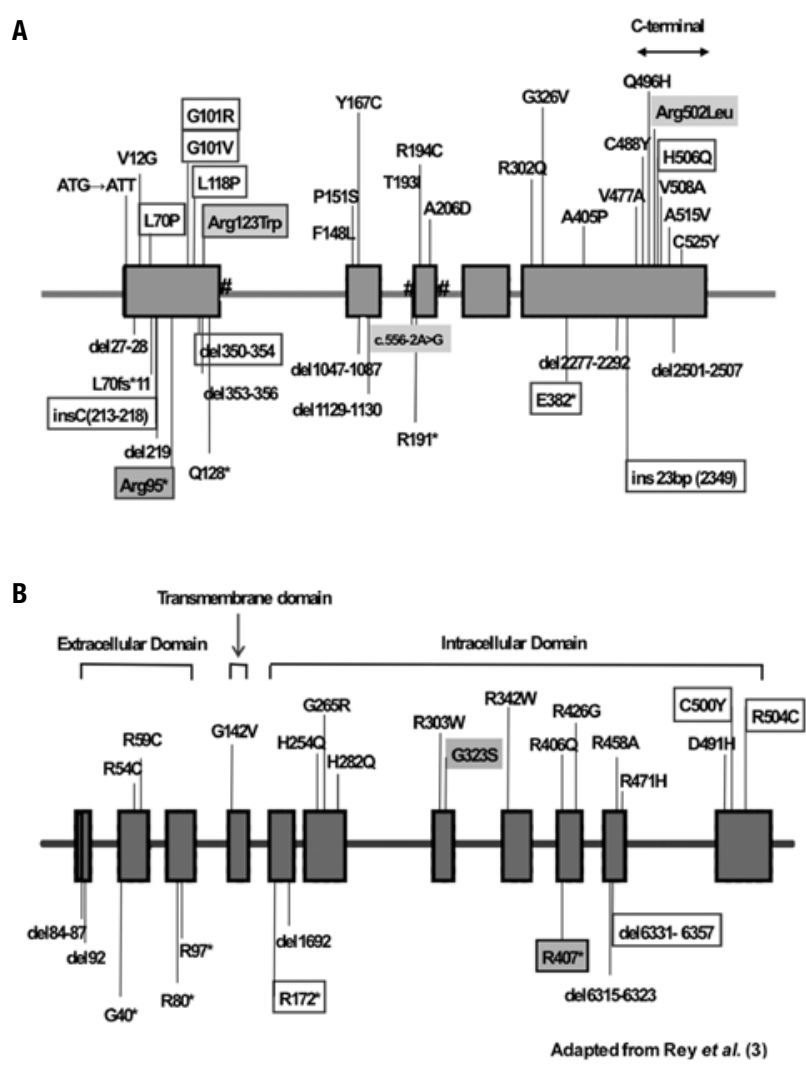

Figure 1. Schematic figure of $A M H(\mathbf{A})$ and $A M H R 2$ (B) genes showing the location of the described mutations.

Missense mutations are shown above the genes. The boxes indicate recurrent mutations; gray background designates the mutations identified in this study. \#: shows the splicing site mutations. 


\section{SUBJECTS AND METHODS}

\section{Patients}

Eight unrelated patients with PMDS were selected. Five patients (patients 1, 2, 3, 4, and 5) were evaluated at the Unit of Endocrinology of Development at Hospital das Clínicas da Faculdade de Medicina da Universidade de São Paulo, and three patients (patients 6,7 and 8) were evaluated in the Interdisciplinary Group for the Study of Sex Determination and Differentiation, Faculdade de Ciências Médicas da Universidade Estadual de Campinas. Fifty five normal males were used as the control group. This study was approved by the Ethical Committee of Hospital das Clínicas da Faculdade de Medicina da Universidade de São Paulo and Faculdade de Ciências Médicas da Universidade Estadual de Campinas. Written informed consent was obtained from all participants of this study.

\section{Clinical evaluation}

The patients presented chronological age from four months to 37 years. Four patients reported having consanguineous parents. The main complaints were presence of inguinal hernia and/or cryptorchidism. All subjects had male external genitalia and uni- or bilateral cryptorchidism. Four of them presented inguinal hernia. The presence of Müllerian derivatives was demonstrated by pelvic ultrasound and/or anatomopathological study. AMH levels were determined in three patients: $64.4 \mathrm{ng} / \mathrm{mL}$ in patient 7 , and $<0.18 \mathrm{ng} / \mathrm{mL}$ in patient 8 (normal levels for their age: $33.8-110.8 \mathrm{ng} / \mathrm{mL}$ ). and $4.6 \mathrm{ng} / \mathrm{mL}$ in patient 6 (normal levels for his age: 63.6132.2). All of them had 46,XY karyotype.

\section{Molecular evaluation}

Genomic DNA samples were obtained from peripheral blood leukocytes using the Salting Out technique (15). DNA was amplified by PCR using specific primers for the $A M H$ (ENSG00000104899) and AMHR2 (ENSG00000135409) genes (Table 1). All PCR reactions were performed with 100-500 ng of genomic DNA, $200 \mu \mathrm{M}$ of dNTP, $20 \mathrm{pmol}$ of each primer, 0.5 units of Go Taq DNA polymerase (Promega Corporations, Madison, WI, USA), $50 \mathrm{mM} \mathrm{KCl}, 1.5 \mathrm{mM}$ $\mathrm{MgCl}_{2}$, and $10 \mathrm{mM}$ Tris- $\mathrm{HCl}$ at $\mathrm{pH} \mathrm{9.0,} \mathrm{in} \mathrm{a} \mathrm{total}$ volume of $25 \mu \mathrm{L}$. PCR conditions were: one cycle of $95^{\circ} \mathrm{C}$ for five minutes, 35 cycles consisting of $97^{\circ} \mathrm{C}$ for 45 seconds; annealing temperatures (Table 1 ) for 45 seconds; $72^{\circ} \mathrm{C}$ for one or two minutes; and a final cycle of $72{ }^{\circ} \mathrm{C}$ for 10 minutes. Amplicons were sequenced following the protocol of the ABI Prism BigDye Terminator Cycle Sequencing Ready Reaction Kit, and were placed in the ABI PRISM 3100 automatic sequencer (Life Technologies Corporation, CA, USA).

Cloning: The amplicon of $A M H$ exon 1 was cloned into pcDNA3.1/v5-His TOPO TA vector. The TOPO $10 \mathrm{E}$. coli were transformed with this vector using $\mathrm{pcD}$ NA3.1/v5-His TOPO TA Expression Kit (Invitrogen, Life Technologies Corporation, CA, USA). Transformed $E$. coli were grown in selective medium (LB with $50 \mu \mathrm{g} / \mathrm{mL}$ ampicilin), the vector was extracted with QIAprep Spin Miniprep Kit (QIAGEN Inc., Valencia, CA, USA), and was sequenced as described above.

In silico analysis: The allelic variants identified were analyzed using the software BDGP Splice Site Prediction by Neural Network (http://www.fruitfly.org/

Table 1. Primer sequences, annealing temperatures, and size of amplicons of $A M H$ and $A M H R 2$

\begin{tabular}{|c|c|c|c|c|}
\hline Gene exon & Forward primer $\left(5^{\prime}-3^{\prime}\right)$ & Reverse primer (5' - 3') & Ann temp $\left({ }^{\circ} \mathrm{C}\right)$ & Size (bp) \\
\hline$A M H 1$ & 1F-AAАСАССССАССТTССАСТC & 1R - CCGGCCCACCTGAAGGAA & 60 & 530 \\
\hline AMH 2 & 2F - CAGGGACAGATCCCAAAGAT & 2R - TACTGCAGACCCTGCAACAA & 60 & 288 \\
\hline AMH 3-4 & 3-4F - GTAGAGCGGGGCTGGGTA & 3-4R - CGCAATTGGAGGAGTTGAGA & 57 & 540 \\
\hline AMH 5 & 5F - CTGGACACCGTGCCCTTC & 5R - TGGGGTCCGAATAAATATGG & 57 & 1080 \\
\hline AMHR2 1-2 & 1-2F - CAGGATGCCCTGTATCTGAAG & $1-2 R-$ acaccccaggatgtgtctgt & 58 & 700 \\
\hline AMHR2 3-4 & 3-4F - CTCTGTTTCCACАСCCСАTT & 3-4R - GGAGAGGGGTCAGAGCTTIT & 58 & 690 \\
\hline AMHR2 5-6 & 5-6F - GACTCCCATGACCTCTCACAA & 5-6R - CATGTAGCCCCCACCTCTAT & 58 & 630 \\
\hline AMHR2 7 & 7F - GGATGGATCAGCCGTCTC & 7R - AGGCAGAATCACAAACATAGCA & 61 & 233 \\
\hline AMHR2 8-9 & 8-9F - AAAAAGAGGGAGGAAGAAAATC & 8-9R - ttggggtgaacctagaatgg & 54 & 670 \\
\hline AMHR2 10 & 10F - CCCTTTCTACATGGTAGGCA & 10R - ACGTCCTTGAAGCCCATGCCCA & 49 & 267 \\
\hline AMHR211 & 11F - TTTTAACCCTGGGGCCCACT & 11RA - GCACACCTACCCCAAGTCAC & 58 & 524 \\
\hline
\end{tabular}


seq_tools/splice.html), Mutation Taster (http://www. mutationtaster.org/), Human Splicing Finder (http:// www.umd.be/HSF/), Polyphen (http://genetics. bwh.harvard.edu/), and Sift (http://sift.jcvi.org/).

\section{RESULTS}

The $A M H$ gene analysis revealed four mutations in five patients. Two of them were novel mutations: c.556$2 \mathrm{~A}>\mathrm{G}$ (intron 2), and p.Arg502Leu (c.1505G $>\mathrm{T}$, exon 5) (Table 2, Figures 1 and 2). The c.556-2A>G mutation, which involves the acceptor splicing site, was identified in homozygous state in three patients $(1,2$ and 6). In silico analysis using the software BDGP Splice Site Prediction by Neural Network, Mutation Taster, and Human Splicing Finder showed that this site is no longer recognized as a splicing site, and predicted that the mutation was the cause of the disease. Four already described allelic variants: c.146 T>G (rs10407022, p.Ser49Ile), c.252G $>$ A (rs61736572, p.Leu84=), c. $303 \mathrm{G}>\mathrm{A}$ (rs61736575, p.Glyl01=), c.555+50G $>\mathrm{A}$ (rs8112524) were also identified in these patients in homozygous state. The frequencies of the allelic variants c.146 T>G (rs10407022), c.252G $>$ A (rs61736572), and c.303G>A (rs61736575) were 23/110 (20.9\%), $2 / 110(1.8 \%)$ and $2 / 110(1.8 \%)$, respectively, in the normal male group. The homozygous p.Arg502Leu (c.1505G $>\mathrm{T}$ ) mutation was identified in patient 7 . Mutation Taster software predicted that this mutation was the cause of the disease; Polyphen suggested that this mutation was probably harmful, and according to Sift software, it would not be tolerated.

In patient 3 , the p.Arg95* (c.283C>T), and p.Argl23Trp (c. $367 \mathrm{C}>\mathrm{T}$ ) mutations in exon $\mathrm{l}$ of $A M H$ were detected in compound heterozygous state. In silico analysis of p.Arg123Trp mutation using the Polyphen software predicted that this variant was probably a damaging alteration, and Sift software suggested a non-tolerated alteration. The p.Arg123Trp mutation was also detected in patient 8 in homozygous state.

AMHR 2 gene sequencing identified the mutation p.Gly323Ser (c.967G $>A$ ) and the allelic variants c.424$30 \mathrm{C}>\mathrm{T}(\mathrm{rs} 2071557)$ and $c^{*}{ }^{*} 13 \mathrm{~T}>\mathrm{C}(\mathrm{rs} 10876455)$ in homozygous state in patient 4 . The mutation p.Arg407* $($ c.1219C $>\mathrm{T})$ was found in patient 5 in homozygous state. In patients 2 and 3 , the heterozygous allelic variant c.1038G $>$ A (rs784890, p.Ser346=) was also detected. In silico analysis of p.Gly323Ser mutation using Mutation Taster and Polyphen software indicated that this alteration was probably damaging and caused the disease.
Table 2. $A M H$ and $A M H R 2$ gene sequencing results

\begin{tabular}{|c|c|c|c|c|}
\hline Patient & $\begin{array}{c}\text { AMH } \\
\text { mutation }\end{array}$ & State & $\begin{array}{c}\text { AMHR2 } \\
\text { mutation }\end{array}$ & State \\
\hline 1 & c. $556-2 A>G$ & Homozygous & $\mathrm{nf}$ & - \\
\hline 2 & c. $556-2 A>G$ & Homozygous & nf & - \\
\hline 3 & $\begin{array}{c}\text { p.Arg95* } \\
\text { (c. 283C>T) } \\
\text { p.Arg123Trp } \\
\text { (c. 367C>T) }\end{array}$ & $\begin{array}{l}\text { Compound } \\
\text { Heterozygous }\end{array}$ & $\mathrm{nf}$ & - \\
\hline 4 & $\mathrm{nf}$ & - & $\begin{array}{l}\text { p.Gly323Ser } \\
(\text { c.967G>A) }\end{array}$ & Homozygous \\
\hline 5 & $\mathrm{nf}$ & - & $\begin{array}{c}\text { p.Arg407* } \\
\text { (c.1219C>T) }\end{array}$ & Homozygous \\
\hline 6 & c. $556-2 A>G$ & Homozygous & $\mathrm{nf}$ & - \\
\hline 7 & $\begin{array}{l}\text { p.Arg502Leu } \\
\text { (c.1505G>T) }\end{array}$ & Homozygous & nf & - \\
\hline 8 & $\begin{array}{l}\text { p.Arg123Trp } \\
\text { (c. 367C>T) }\end{array}$ & Homozygous & nf & - \\
\hline
\end{tabular}

nf: not found.

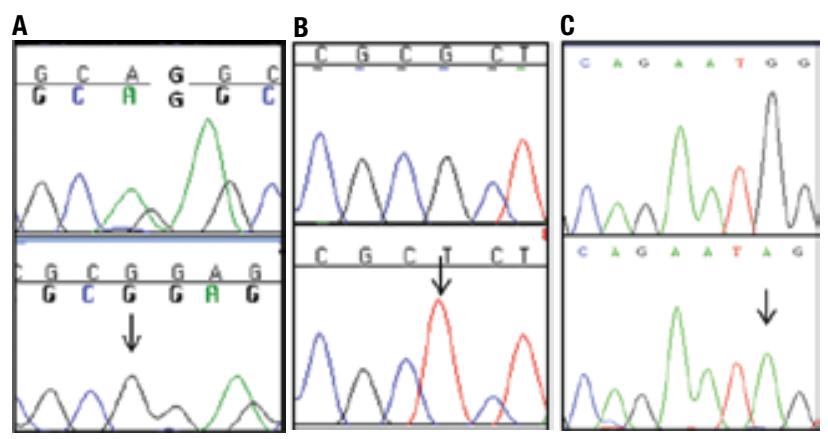

Figure 2. Electropherograms showing the three novel mutations identified in this study: A: c.556-2A>G; B: p.Arg502Leu (c.1505G>T); C: p.Gly323Ser (c.967G>A).

Normal sequences of the genes are shown above and mutated sequences are shown below. Arrows indicate nucleotide substitutions.

\section{DISCUSSION}

PDMS is one of the rarest causes of development disorders of male internal genitalia, and it is usually diagnosed during surgical correction of hernia inguinalis. Mutations in $A M H$ or $A M H R 2$ genes, in similar proportions, are the cause of approximately $85 \%$ of PMDS cases $(6,16,17)$. In the remaining patients, the cause of the PMDS is unknown (17).

Patients with $A M H$ or $A M H R 2$ gene mutations have no differences in anatomical phenotype. Normally, AMH levels are measurable during childhood and decrease at puberty. Patients with $A M H$ gene defects show low AMH levels from birth, whereas patients with mutations in $A M H R$ have elevated AMH levels, indicating insensitivity of the target tissues (18). At 
post-pubertal age, AMH levels cannot be used to select which gene to study in PMDS patients (3).

Currently, the majority of $A M H$ mutations described are located especially in exon 1 , and in the 3 ' portion of exon 5, which are important regions for AMH bioactivity (17). In the present study, the $A M H$ p.Arg95*, p.Arg 123Trp and p.Arg502Leu mutations that were identified were located in these regions, and in silico analyses of p.Arg123Trp and p.Arg502Leu mutations predicted that they were the genetic causes of PMDS in these patients. In addition, Arg502 amino acid is conserved in several organisms, showing its importance in this protein.

The p.Arg502Leu mutation was identified in patient 7, who presented normal levels of AMH for his age, indicating that this mutation, because of its position, might affect hormone bioactivity, and not its secretion rate. Menabo and cols. also described an Italian patient with $A M H$ mutations and normal AMH levels (10).

The previously described mutations in $A M H$, p.Arg95* and p.Arg123Trp, were found in compound heterozygous state in patient 3 , demonstrated by exon 1 amplicon cloning. The p.Arg95* mutation leads to a premature stop codon, resulting in a truncated protein, lacking a large part of the normal protein sequence (19). Formerly, Imbeaud and cols. described a PMDS patient with undetectable AMH levels and p.Arg123Trp mutation (16). These findings were similar to those of patient 8 .

The novel homozygous c.556-2A>G mutation in patients 1,2 , and 6 , located in the acceptor splicing site, abolished this site according to in silico analysis, indicating a possible genetic cause of the disease. Interestingly, these patients had the same three allelic variants near this mutation, which might indicate a founder effect.

AMHR 2 mutations were identified in two patients. The p.Gly323Ser mutation, present in patient 4 , is located in exon 7, which is a component of the protein kinase domain in the cytoplasmic portion of AMHR2. Glycine is a polar and neutral amino acid, and serine is a nonpolar and hydrophobic amino acid; these distinct amino acid characteristics indicate that the amino acid change might affect protein conformation. In addition, Gly323 is highly conserved among mammals.

The p.Arg $407^{*}$ mutation leads to a premature stop codon. The resulting truncated protein lose a significant portion of the serine/threonine kinase domain in the intracellular portion of the AMHR responsible for the bioactivity of the protein (5). Abduljabbar and cols. also identified this mutation in a family from Saudi Arabia that had consanguineous parents and four affected males. Molecular models of the intracellular domains of the wild type and mutated receptors showed that the mutated protein lost most of the $\alpha \mathrm{F}$ helix and all of the four $\alpha$-helices at the $\mathrm{C}$ terminus (5).

In conclusion, a likely molecular etiology was found in these eight patients with PMDS. Four mutations in the $A M H$ gene and two in $A M H R 2$ were identified. Three of them are novel mutations, c.556-2A>G and p.Arg502Leu in $A M H$; and p.Gly323Ser in AMHR2. Further functional studies are necessary to confirm the in silico analysis. The possibility of a founder effect of the novel $A M H$ mutation (c.556-2A>G) found in three Brazilian patients with the PMDS cannot be excluded.

Acknowledgements: this study was supported by grants from Conselho Nacional de Desenvolvimento Científico e Tecnológico (CNPq), n. 305743/2011-2 to B.B.M, n. 314392/2009-2 to G.G.J. and n. 302084/2009-6 to A.T.G.; and from Fundação de Amparo à Pesquisa do Estado de São Paulo (Fapesp) 06/50999-0 to A.Z.N.

Disclosure: no potential conflict of interest relevant to this article was reported.

\section{REFERENCES}

1. Jost A. Problems of fetal endocrinology: the gonadal and hypophyseal hormones. Recent Prog Horm Res. 1953;8:379-418.

2. Farikullah J, Ehtisham S, Nappo S, Patel L, Hennayake S. Persistent Müllerian duct syndrome: lessons learned from managing a series of eight patients over a 10-year period and review of literature regarding malignant risk from the Mullerian remnants. BJU Int. 2012; Epub 2012 Apr 30.

3. Rey R, Picard JY, Josso N. Síndrome de Persistência dos Ductos de Müller. In: Guerra ATM, Guerra Júnior G, editors. Menino ou Menina? Distúrbios da Diferenciação do Sexo. 2.ed. Rubio; 2010. p. 279-95.

4. Hutson JM, Davidson PM, Reece LA, Baker M, Zhou B. Failure of gubernacular development in the persistent Müllerian duct syndrome allows herniation of the testes. Pediatr Surg Int. 1994;9:544-6.

5. Abduljabbar M, Taheini K, Picard JY, Cate RL, Josso N. Mutations of the AMHType II receptor in two extended families with persistent Müllerian duct syndrome: lack of phenotype/genotype correlation. Horm Res Paediatr. 2012;77(5):291-7.

6. Imbeaud S, Faure E, Lamarre I, Mattei MG, di Clemente N, Tizard $\mathrm{R}$, et al. Insensitivity to anti-Müllerian hormone due to a mutation in the human anti-Müllerian hormone receptor. Nat Genet. 1995;11(4):382-8.

7. Cate RL, Mattaliano RJ, Hession C, Tizard R, Farber NM, Cheung $A$, et al. Isolation of the bovine and human genes for Müllerian inhibiting substance and expression of the human gene in animal cells. Cell. 1986;45(5):685-98. 
8. Josso N, di Clemente N. TGF-beta family members and gonadal development. Trends Endocrinol Metab. 1999;10(6):216-22.

9. Josso N, Belville C, di Clemente N, Picard JY. AMH and AMH receptor defects in persistent Müllerian duct syndrome. Hum Reprod Update. 2005;11(4):351-6.

10. Menabo S, Balsamo A, Nicoletti A, Gennari M, Pirazzoli P, Cicognani $A$, et al. Three novel $A M H$ gene mutations in a patient with persistent Müllerian duct syndrome and normal AMH serum dosage. Horm Res. 2008;70(2):124-8.

11. van der Zwan YG, Bruggenwirth HT, Drop SL, Wolffenbuttel $K P$, Madern GC, Looijenga LH, et al. A novel AMH missense mutation in a patient with persistent Müllerian duct syndrome. Sex Dev. 2012; Epub 2012 Jul 11.

12. Baarends WM, van Helmond MJ, Post M, van der Schoot PJ, Hoogerbrugge JW, de Winter JP, et al. A novel member of the transmembrane serine/threonine kinase receptor family is specifically expressed in the gonads and in mesenchymal cells adjacent to the Müllerian duct. Development. 1994;120(1):189-97.

13. di Clemente N, Wilson C, Faure E, Boussin L, Carmillo P, Tizard R, et al. Cloning, expression, and alternative splicing of the receptor for anti-Müllerian hormone. Mol Endocrinol. 1994;8(8):1006-20.
14. Belville C, Marechal JD, Pennetier S, Carmillo P, Masgrau L, Messika-Zeitoun $\mathrm{L}$, et al. Natural mutations of the anti-Müllerian hormone type II receptor found in persistent Müllerian duct syndrome affect ligand binding, signal transduction and cellular transport. Hum Mol Genet. 2009;18(16):3002-13.

15. Miller SA, Dykes DD, Polesky HF. A simple salting out procedure for extracting DNA from human nucleated cells. Nucleic Acids Res. 1988;16(3):1215.

16. Imbeaud S, Carre-Eusebe D, Rey R, Belville C, Josso N, Picard JY. Molecular genetics of the persistent Müllerian duct syndrome: a study of 19 families. Hum Mol Genet. 1994;3(1):125-31.

17. Josso N, Picard JY, Rey R, di Clemente N. Testicular anti-Müllerian hormone: history, genetics, regulation and clinical applications. Pediatr Endocrinol Rev. 2006;3(4):347-58.

18. Rey RA, Codner E, Iniguez G, Bedecarras P, Trigo R, Okuma C, et al. Low risk of impaired testicular Sertoli and Leydig cell functions in boys with isolated hypospadias. J Clin Endocrinol Metab. 2005;90(11):6035-40.

19. Imbeaud S, Belville C, Messika-Zeitoun L, Rey R, di Clemente N, Josso N, et al. A 27 base-pair deletion of the anti-Müllerian type II receptor gene is the most common cause of the persistent Müllerian duct syndrome. Hum Mol Genet. 1996;5(9):1269-77. 